\title{
Indonesia Most Trusted Company dan Nilai Perusahaan
}

\section{Yusuf Kurniawan}

Jurusan Manajemen Fakultas Ekonomi dan Bisnis Universitas Gajayana Malang Jl. Mertojoyo Blok L, Malang, 65144, Indonesia

\section{Info Artikel}

Sejarah Artikel:

Diterima: 25 Mei 2018

Disetujui: 25 Juni 2018

Tersedia daring: Juli 2018

\section{Keywords:}

Capital structure; Corporate

Governance; devident policy;

Firm Value; Indonesia Most

Trusted Company.

ISSN (print) : 2598-7763

ISSN (online): 2598-7771

$\triangle$ Corresponding Author:

M. Yusuf Kurniawan:

Tel. /Fax. (0341).562528

E-mail:fitria.ariyani82@gmail.com

\section{Abtract}

This study analyzes the value of firms in Indonesia as the Most Trusted Company. Independent variables include: Good Corporate Governance (GCG), capital structure, dividend policy and profitability. While the dependent variable is the value of the company. Company value is proxied by Price Book Value (PBV). The purpose of this study was to analyze the effect of capital structure, dividend policy, profitability and GCG on corporate value, either simultaneously or partially. This research was conducted at public go public company in Indonesia which entered into Indonesia Most Trusted Companies in 2015. The research population is a company that go public in Bursa Efek Indonesia. The sampling technique uses purposive sampling. The sample of research company that entered Indonesia Most Trusted Company in 2015. Indonesia Most Trusted Company is a company that apply GCG and published SWA Magazine. The sample size is 25 companies. The analysis technique used multiple regression. The results showed that simultaneously GCG, capital structure, dividend policy and profitability affect the value of the company. Partially, capital structure and profitability have an effect on company value, while dividend policy and GCG do not influence to company value..

Citation: Kurniawan, Y.M., (2018). Indonesia Most Trusted Company dan Nilai Perusahaan. Accounting and Financial Review, 1 (1)

\begin{abstract}
Abstraks
Penelitian ini menganalisis nilai perusahaan pada Indonesia Most Trusted Companies. Variabel independent meliputi: Good Corporate Governance (GCG), struktur modal, kebijakan deviden dan profitabilitas. Sedangkan variabel dependen berupa nilai perusahaan. Nilai perusahaan diproksikan dengan Price Book Value (PBV). Tujuan penelitian adalah untuk menganalisis pengaruh struktur modal, kebijakan deviden, profitabilitas dan GCG terhadap nilai perusahaan, baik secara simultan maupun parsial. Penelitian ini dilakukan pada perusahaan go publik di BEI yang masuk Indonesia Most Trusted Companies tahun 2015. Populasi penelitian merupakan perusahaan yang go publik di Bursa Efek Indonesia. Teknik sampling digunakan purposive sampling. Sampel penelitian perusahaan yang masuk Indonesia Most Trusted Company tahun 2015. Indonesia Most Trusted Company merupakan perusahaan yang menerapkan GCG dan dipublikasikan Majalah SWA. Jumlah sampel sebanyak 25 perusahaan. Teknik analisis digunakan regresi berganda. Hasil penelitian menunjukkan bahwa secara simultan GCG, struktur modal, kebijakan deviden dan profitabilitas berpengaruh terhadap nilai perusahaan. Secara parsial struktur modal dan profitabilitas berpengaruh terhadap nilai perusahaan, sedangkan kebijakan deviden dan GCG tidak berpengaruh terhadap nilai perusahaan.
\end{abstract}

JEL Classification: G32, G34 


\section{PENDAHULUAN}

Manajemen sebagai agen pada prinsipnya akan berusaha bagaimana kemakmuran pemilik mengalami peningkatan nilai perusahaan yang meningkat. Pemegang saham selaku principle mempunyai ekspektasi adanya peningkatan kemakmurannya (welfare) dari perusahaannya. Para pemilik perusahaan berharap nilai perusahaannya tinggi (Hermuningsih, 2013). Manajer sebagai agent yang diberi tanggungjawab oleh pemilik untuk mengelola perusahaan dalam upaya agar nilai perusahaan meningkat. Manajemen sebagai agent berusaha memenuhi ekspektasi pemilik, yaitu pemegang saham, dengan cara mengoptimalkan nilai perusahaan. Manajemen akan mengambil kebijakan dan mengelola resources perusahaan, sehingga daya saing perusahaan meningkat, yang selanjutnya kemakmuran pemilik akan cenderung meningkat.

Manajamen akan berupaya meningkatkan nilai perusahaan tercermin dari pelaksanaan fungsi manajemen keuangan. Manajemen akan menentukan sumber dan penggunaan dana untuk memaksimalkan laba perusahaan. Kebijakan perusahaan terkait dengan keuangan akan didasari oleh pertimbangan risiko dan return, baik jangka pendek maupun jangka panjang. Dimana kebijakan ini akan terkait dan berdampak pada posisi keuangan perusahaan yang selanjutnya akan berdampak pada nilai perusahaan. Manajemen akan berusaha meningkatkatkan nilai perusahaan. Perusahaan dengan nilai perusahaan yang semakin tinggi mencerminkan ekspekstasi pasar terhadap prospek perusahaan semakin tinggi (Hermuningsih \& Wardani, 2009). Price books value (PBV) merupakan salah satu proksi yang nilai perusahaan. Nilai PBV lebih dari satu menunjukkan harga saham lebih besar dari nilai bukunya.

Keputusan perusahaan yang diambil manajer mempertimbangkan kepentingan semua stakeholder baik jangka pendek maupun jangka panjang (Jensen \& Meckling, 1976), (Margaritis \& Psillaki, 2010) Kepentingan stakeholder bukan hanya saat ini tetapi juga di masa yang akan datang. Kemampuannya mencapai tujuan serta kemam-puan mengimplementasikan strategi untuk men-capai tujuan ini merupakan faktor penilaian kinerja manajemen.

Nilai perusahaan akan dipengaruhi oleh faktor fundamental dan kinerja perusahaan, dan juga faktor eksternal perusahaan. Banyak faktor yang berpengaruh terhadap nilai perusahaan, antara lain: profitabilitas, growth opportunity, size, struktur modal, good corporate governance, kebijakan deviden, keputusan pendanaan (Hermuningsih, 2013; 2012; Hermuningsih dan Wardani, 2009; Subagyo, 2011; Saputra, 2010). Faktor eksternal perusahaan berupa: pertumbuhan ekonomi, kurs, inflasi dan psychology pasar. Hasil penelitian menunjukkan faktor yang mempengaruhi nilai perusahaan tidak konsisten.

Perusahaan bukan hanya bertujuan memberikan laba, namun juga harus memberikan manfaat bagi stakeholdernya. Perusahaan agar memberikan manfaat, maka perusahan harus tumbuh sehat dan berkelanjutan. Good Corporate Governance (GCG) atau Tata kelola perusahaan yang baik adalah pondasi penting bagi perusahaan agar mampu tumbuh sehat dan berkembang. Praktek GCG meliputi prinsip-prinsip: transparan-si, akuntabilitas, responsiveness, independensi dan fairness dengan baik. Pengelolaan perusahaan yang baik sangat dibutuhkan, baik itu stakeholder mau-pun shareholder karena akan menentukan masa de-pan perusahaan.

Perusahaan yang mampu mengimplementasikan GCG dalam pengelolaan perusahaan menjadi indikator penting bagi investor, karena investor akan merasa lebih rasa aman untuk menginvestasikan dananya. Walaupun tidak ada brenchmark terkait dengan korelasi antara GCG dengan investasi di pasar modal. Para pemegang saham dan investor ketika mengambil keputusan untuk meng-investasikan pada suatu perusahaan akan selalu dihadapkan dengan risiko. Kepercayaan investor terhadap suatu perusahaan menjadi sangat penting. Kepercayaan investor terhadap suatu perusahaan tumbuh seriring dengan implementasi GCG (Emirzon, 2006). Perusahaan yang berkomitmen dalam mengimplimentasikan GCG secara konsistensi dalam pengelolaan perusahaan akan mampu meningkatkan kepercayaan investor. Implementasi GCG akan cenderung berdampak positif terhadap Fundamental dan kinerja perusahaan, valuasi dan harga saham. Perushaan dengan menerapkan GCG, membuat investor dapat mengatahui rekam jejak emiten itu bagaimana. Ketika kepercayaan investor tinggi, maka berdampak pada nilai perusahaan yang cenderung meningkat pula. Implementasi GCG merupakan faktor penting da-lam meningkatkan nilai perusahaan (Dewi, Yuni-arta, \& Dewi, 2014), (Saputra, 2010). Penelitian Hey-von et al. (2017) menemukan bahwa divesifikasi gender anggota dewan direksi berpengaruh positif terhadap kinerja perusahaan. Dalam upaya mendorong penerapan tata kelola perusahaan yang baik The Indonesia Institute for Corporate Governance (IICG) dan Majalah SWA menyelenggarakan GCG Award. Ajang ini merupakan salah satu ajang yang 
sangat bergengsi bagi perusahaan-perusahaan dalam melakukan tata kelola perusahaan. Perusahaan yang memperoleh GCG Award dikenal de-ngan Indonesia Most Trusted Companies. Perusaha-anperusahaan yang masuuk dalam Indonesia Most Trusted Companies merupakan perusahaan-perusahaan yang telah mengimpementasikan GCG dengan sangat baik.

Nilai perusahaan menunjukkan respon investor terhadap kebijakan dan kinerja perusahaan. Kebijakan merupakan upaya yang dilakukan oleh manajemen perusahaan dalam upaya mencapai kinerja perusahaan yang optimal. Kebijakan yang diambil manajemen antara lain terkait dengan kebijakan pendanaan dan kebijakan deviden. Kebijakan pendanaan merupakan salah satu kebijakan yang penting, karena akan berdampak dan terkait dengan kinerja perusahaan, prospek perusahaan di masa yang akan datang.

Penelitian terkait dengan pengaruh kebijakan pendanaan yang tercermin dari struktur modal terhadap nilai perusahaan menunjukkan hasil yang tidak konsisten. Penelitian Hermuningsih (2013) menunjukkan bahwa struktur modal berpengaruh terhadap nilai perusahaan. Sedangkan penelitian Bilayudha dan Kiswanto (2015); Haryanto (2014); Mardiyati, Gatot dan Putri (2012); Artini dan Puspaningsih (2011) kebijakan hutang tidak berpengaruh terhadap nilai perusahaan.

Kebijakan deviden merupakan kebijakan yang akan berpengaruh pada respon investor terhadap suatu perusahaan. Ketika perusahaan mengambil kebijakan untuk mengeluarkan deviden dari laba, maka laba ditahan perusahaan akan cenderung lebih sedikit. Padahal laba ditahan merupakan sumber modal yang dapat digunakan untuk modal perusahaan. Pandangan investor terhadap kebijakan deviden dapat positif dan juga dapat negatif terhadap suatu perusahaan. Perusahaan yang membagikan dividen menunjukkan kinerja perusahaan tersebut baik. Di sisi lain investor akan melihat perusahaan yang membagikan deviden tidak mampu melihat peluang usaha.

Hasil penelitian pengaruh GCG, struktur modal, kebijakan deviden dan profitabilitas menunjukkan hasil yang tidak konsisiten. Penelitian ini bertujuan untuk menganalisis GCG, struktur modal, kebijakan deviden, dan profitabilitas terhadap nilai perusahaan pada Indonesia Most Trusted Companies.

\section{PENGEMBANGAN HIPOTESIS}

Perusahaan yang mengimplementasikan GCG secara konsisten dan berkelanjutan akan ber- dampak pada citra perusahaan yang ikut meningkat, sehingga akan berdampak positif di mata investor. Pengelolaan perusahaan dengan prinsip GCG tidak hanya berorientasi pada kepentingan jangka pendek, tetapi juga jangka panjang. Manajemen tidak hanya berorientasai pada keuntungan (profit) semata, namun juga akan berorientasi pada masyarakat (people) dan lingkungan (planet). Perusahaan yang mengimplementasikan GCG, dengan prinsip-prinsip GCG akan cenderung berdampak positif pada kepercayaan investor. Perusahaan akan dikelola dengan memperhatikan semua stakehorlder dan shareholder. Hasil penelitian menunjukkan bahwa GCG berpengaruh terhadap nilai perusahaan (Haryanto, 2014; Wardoyo \& Veronica, 2013; Juniarti, 2013). Hipotesis dalam penelitian ini dapat dirumuskan sebagai berikut:

$\mathrm{H}_{1}$ : GCG berpengaruh terhadap nilai perusahaan.

Salah satu kebijakan yang harus diambil manajemen adalah kebikana terkait dengan pendanaan. Manajemen dalam membiayai operasional perusahaan dituntut untuk menentukan sumbersumber pendanaannya, yang tercermin dari struktur modal perusahaan. Struktur modal perusahaan merupakan trade-off antara tingkat pengembalian dan risiko. Struktur modal perusahaan menunjukkan rasio antara hutang dengan ekuitas atau modal sendiri. Struktur modal akan berdampak langsung terhadap posisi keuangan perusahaan (Hermuningsih, 2013). Pengaruh struktur modal terhadap nilai perusahaan dikemukanan oleh Jandik dan Makhija (2005), yaitu entranchment dan alignment effect. Dalam analisis alignment effect, perusahaan dengan pendanaan dominan dari hutang akan cenderung nilai perusahaan meningkat. Perusahaan dengan pembiayaan dari hutang mengindikasikan bahwa perusahaan mempunyai komitmen untuk meningkatkan kinerjanya. Perilaku opportunities dari manajemen dapat ditekan dengan adanya hutang.

Dalam entranchment effect, perusahaan yang membiayai dari hutang, maka manajer akan menggunakan dana tersebut untuk kepentingan pribadi manajer (Jandik \& Makhija, 2005). Perusahaan dengan dengan hutang yang besar akan biaya bunga. Di sisi lain hutang yang diambil perusahaan tidak mampu kinerja perusahaan, sehingga tidak berdampak pada nilai perusahaan.

Hasil penelitian menunjukkan hasil yang tidak konsisten. Penelitian Hermuningsih (2013) enunjukkan bahwa struktur modal berpengaruh terhadap nilai perusahaan. Hipotesis dalam penelitian ini dapat dirumuskan sebagai berikut:

$\mathrm{H}_{2}$ : Struktur modal berpengaruh terhadap nilai 


\section{perusahaan}

Pembayaran deviden menjadi salah satu alat komunikasi manajemendengan pasar terkait dengan kinerja perusahaan. Dalam teori kandungan informasi menjelaskan bahwa pasar merespon peningkatan deviden sebagai kinerja perusahaan dan prospeknya. Pembayaran deviden dianggap sebagai sinyal kinerja perusahaan. Sinyal positif dari perusahaan dari informasi deviden diharapkan akan menarik minat investor (Artini dan Puspaningsih, 2011). Perusahaan yang mampu membayar deviden dengan konsisten dan meningkat setiap tahunnya merupakan sinyal positif terhadap prospek perusahaan. Perusahaan yang tidak membayar dividen atau devidennya menurun dianggap sebagai sinyal negatif oleh investor terhadap prospek perusahaan (Nafi'ah, 2013). Namun, sebagian investor menangkap pembayaran deviden sebagai sinyal negatif. Ketika perusahaan membayar deviden menunjukkan manajemen tidak mampu melihat peluang yang menguntungkan, sehingga memilih membagikan laba perusahaan dalam bentuk deviden daripada untuk menambah modal melalui laba yang ditahan.

Hasil penelitian pengaruh kebijakan deviden terhadap nilai perusahaan menunjukkan hasil yang tidak konsisten. Penelitian yang dilakukan oleh Hasnawati (2005), Rahmawati \& Akram (2007), AlMalkawi, (2007); Artini dan Puspaningsih (2011) menunjukkan bahwa kebijakan deviden berpengaruh terhadap nilai perusahaan. Hipotesis dalam penelitian dapat dirumuskan sebagai berikut: $\mathrm{H}_{3}$ : Kebijakan deviden berpengaruh terhadap nilai perusahaan.

Nilai perusahaan menunjukkan persepsi investor terhadap prospek suatu perusahaan. Perusahaan dengan kinerja yang bagus merupakan indikator bahwa perusahaan tersebut mempunyai prospek bagus dan sebaliknya. Kinerja perusahaan dapat dilihat dari profitabilitas perusahaan. Profitabilitas perusahaan menunjukkan kemampuan perusahaan dalam menghasilkan laba. Perusahaan dengan profitabilitas yang semakin tinggi mengindikasikan prospek perusahaan tersebut semakin baik, sehingga respon investor akan merespon positif dan nilai perusahaan akan meningkat (Sujoko dan Ugi, 2007).

Earnings power dari aset perusahaan akan menentukan nilai perusahaan. Earnings power yang semakin tinggi menunjukkan semakin efisien perputaran aset, sehingga profit margin perusahaan akan semakin tinggi, dan nilai perusahaan akan meningkat. Beberapa hasil penelitian menunjukkan bahwa profitabilitas berpengaruh positif signifikan terhadap nilai perusahaan (Haryanto, 2014; Hermuningsih, 2013). Hipotesis dalam penelitian ini dapat dirumuskan sebagai berikut:

$\mathrm{H}_{4}$ : Profitabilitas berpengaruh terhadap nilai perusahaan

\section{DATA DAN METODE}

Penelitian ini merupakan penelitian deskriptif kuantitatif, yang menjelaskan hubungan sebab akibat. Populasi yang diguunakan dalam penelitian ini adalah perusahaan yang go public di Bursa Efek Indonesia (BEI). Teknik sampling digunakan dengan metode purposive sampling. Kriteria dalam penentuan sampel perusahaan masuk dalam Indonesia Most Trusted Companies 2015. Jumlah sampel dalam penelitian ini sebanyak 23 perusahaan (Tabel 1). Sumber data yang digunakan data sekunder yang bersumber dari 1). Majalah SWA dan 2). http: idx.co.id. Jenis data berupa data kuantitif, yaitu data laporan keuangan dan harga saham. Variabel bebas dalam penelitian ini meliputi: 1) GCG diproksikan dengan nilai Good Corporate Perception Index (GCPI), 2) struktur modal, yang diproksikan dengan Debt to Equity Ratio (DER), 3) kebijakan deviden diukur dengan deviden Payout Ratio (DPR), 4) Profitabilitas diukur dengan ROA. Variable terikat adalah nilai perusahaan. Price Book Value (PBV) digunakan sebagai proksi untuk nilai perusahaan. Teknik pengambilan data dilakukan dengan dokumentasi. Teknik analisis data digunakan dengan regresi linear berganda. Untuk mengeliminir ukuran variabel yang berbeda, maka model persamaan regresi berganda dirumuskan sebagai berikut (Chandrarin, 2017):

$$
Y=\beta_{1} X_{1}+\beta_{2} X_{2}+\beta_{3} X_{3}+\beta_{4} X_{4}+e
$$

Di mana Y: Nilai Perusahaan, $\beta_{1-4}$ : Koefisien regresi; $\mathrm{X}_{1}$ : Good Coprporate Perception Index (GCPI); $\mathrm{X}_{2}$ : Struktur Modal (DER); $\mathrm{X}_{3}$ : Kebijakan deviden (DPR); $\mathrm{X}_{4}$ : Profitabilitas (ROA) dan e: Error

\section{HASIL}

Pada tahun 2015 terdapat 23 perusahaan yang masuk dalam Indonesia Most Trusted Companies. Perusahaan yang masuk dalam Most Trusted Companies terdiri berbagai industri, baik yang bergerak di perusahaan pertambangan, manufaktur maupun jasa. Perusahaan yang menjadi sampel dalam penelitian ini sejumlah 23 bank.

Hasil analisis deksripsi data dari masingmasing varibel penelitian disajikan pada tabel 1 . 
Nilai perusahaan yang diproksikan dengan PBV reratanya sebesar 5,86. Nilai PBV yang semakin tinggi menunjukkan semakin tinggi nilai perusahaan. Nilai PBV tertinggi sebesar 45,03 dan terendah 0,67 . Nilai GCPI yang semakin tinggi mencerminkan tata kelola perusahaan semakin baik. Rerata nilai GCPI sebesar 75,99, dengan nilai GCPI tertinggi sebesar 79,13 dan terendah 72,78. Nilai rerata DER sebesar 2,34 dengan DER tertinggi sebesaar 7,21 dan terendah 0,27. Sedangkan DPR tertinggi sebesar 0,86 dan terendah 0,00 dengan rerata sebesar 0,27. Perusahaan yang masuk Indonesia Most Trusted Companies tidak semuanya membagikan deviden. Kondisi ini karena tidak semua perusahaan membukukan laba, hal ini terlihat dari nilai profitabilitas (ROA) dimana ada perusahaan yang mengalami kerugian. Rerata profitabilitas perusahaan baik, yaitu sebesar 9,10 (Tabel 1).

Data penelitian berdistribusi normal, hal ini ditunjukkan dari sebaran titik pada diagram Normal P-P Plot Regression yang berada di sekitar garis diagonal. Sedangkan dari asumsi klasik, untuk uji heteroskedasitas menunjukkan titik di diagram scatterplot menyebar dan tidak membentuk pola. Sehingga dapat diambil keputusan tidak terjadi heteroskedasitas. Uji multikolinieritas, yaitu untuk melihat apakah ada korelasi yang tinggi antar variabel bebas menunjukkan tidak terjadi multikolineritas. Hal ini ditunjukkan dari nilai VIF yang berada di bawah 10 (Tabel 2). Uji autokorelasi menunjukkan nilai DW sebesar 2,131 (Tabel 2). Nilai DW dengan $n$ sebanyak 23 diperoleh nilai dU sebesar 1.7855. Nilai DW berada diantara dU dan 4-dU $(2,2145)$, sehingga dapat diambil keputusan tidak terjadi autokorelasi.

Tabel 1. Diskripsi data Penelitian

\begin{tabular}{lrrrrr}
\hline & DER & DPR & ROA & GCPI & PBV \\
\hline Rerata & 2,34 & 0,27 & 9,10 & 75,99 & 5,86 \\
Tertinggi & 7,21 & 0,86 & 40,18 & 79,13 & 45,03 \\
Terendah & 0,27 & 0,00 & $-3,49$ & 72,78 & 0,67 \\
\hline
\end{tabular}

Sumber: Data diolah

Tabel 2. Ringkasan Hasil Analisis Data

\begin{tabular}{|c|c|c|c|c|c|c|}
\hline Variabel & & $\begin{array}{r}\text { Standardized } \\
\text { Coefficients Beta }\end{array}$ & $\mathrm{t}$ & Sig. & VIF & Keterangan \\
\hline GCPI & & $-0,141$ & $-1,514$ & 0,147 & 1,120 & Tidak Signifikan \\
\hline DER & & 0,333 & 3,370 & 0,003 & 1,264 & Signifikan \\
\hline DPR & & $-0,238$ & $-2,055$ & 0,055 & 1,741 & Tidak Signifikan \\
\hline ROA & & 1,119 & 9,101 & 0,000 & 1,957 & Signifikan \\
\hline $\mathrm{R}^{2} \mathrm{Adj}$ & : 0,830 & & & & & \\
\hline$F_{\text {hitung }}$ & : 27,841 & & & & & \\
\hline $\mathrm{F}_{\text {Prob }}$ & $: 0,000$ & & & & & \\
\hline DW & : 2,131 & & & & & \\
\hline
\end{tabular}

Sumber: Hasil Olahan

Berdasarkan hasil analisis yang disajikan pada Tabel 2 menunjukkan hipotesis 1 dan 3 ditolak. Hal ini berarti GCG dan kebijakan deviden pada perusahaan yang masuk Indonesia Most Trusted Companies tidak berpengaruh terhadap nilai perusahaan. Hasil penelitian menunjukkan hipotesis 2 dan 4 . Kebijakan strukttur modal dan profitabilitas perusahaan pada Indonesia Most Trusted Companies berpengaruh terhadap nilai perusahaan. Kebijakan struktur modal berpengaruh terhadap nilai perusahaan dengan arah positif. Hal ini menunjukkan bahwa perusahaan dengan struktur modal yang semakin tinggi, akan direspon positif oleh investor dengan naiknya nilai perusahaan. Profitabilitas berpengaruh terhadap nilai perusahaan dengan arah positif. Nilai koefisien determinasi, yang ditunjukkan dengan nilai $\mathrm{R}^{2}$ adjusted sebesar 0,830 . Hal ini menunjukkan bahwa variabel bebas yang ditunjukkan oleh GCG, struktur modal, kebijakan deviden dan profitabilitas mampu menjelaskan varian nilai perusahaan sebesar 83 persen, sedang sisanya 17 persen dijelaskan oleh variabel lain diluar model. Nilai koefisien determinasi sebesar 83 persen, menunjukkan bahwa variabel yang digu-nakan dalam penelitian ini mampu menjelaskan varian nilai perusahaan besar

\section{PEMBAHASAN}

\section{Pengaruh GCG terhadap Nilai Perusahaan}

Hasil penelitian menunjukkan bahwa GCG 
yang diproksikan dengan nilai GCPI (Good Corporate Perception Index) tidak berpengaruh terhadap nilai perusahaan. Hal ini menunjukkan bahwa perusahaan yang menerapkan GCG belum tentu secara langsung akan direspon positif oleh pasar. Hal ini dapat terjadi karena investor rata-rata adalah berorientasi jangka pendek. Sedangkan GCG cenderung berorientasi jangka panjang. Investor jangka pendek lebih cenderung berorientasi pada gain, yaitu selisih harga jual dan harga beli. Para investor ini akan lebih cenderung melihat dari sentimen pasar dan gerakan harga saham. Hasil ini bukan berarti penerapan tata kelola tidak penting. Perusahaan yang go publik telah banyak yang menerapkan GCG, namun demikian hanya sedikit yang ikut dalam GCG Award setiap tahunnya. Hal ini mengindikasikan walaupun perusahaan telah menerapkan GCG namun belum berani dinilai oleh pihak eksternal. Kondisi demikian tentunya juga akan berpengaruh pada respon investor pada penerapan GCG oleh perusahaan.

Investor di pasar modal Indonesia dalam melakukan investasi lebih cenderung berharap memperoleh return dari capital gain. Artinya lebih investor yang merupakan investor jangka pendek, sehingga kurang mempertimbangkan apakah perusahaan tersebut mengimplikasikan GCG atau tidak. Investor lebih cenderung melihat dari siklus harga saham dipasar. Gerakan harga saham dalam rentang waktu tertentu menjadi pertimbangan penting para investor jangka pendek.

Hasil penelitian ini tidak konsisten dengan temuan penelitian Emirzon (2006), dan Wardoyo dan Veronica (2013). Temuan ini mendukung penelitian Siallagan dan Machfoedz (2006).

\section{Pengaruh Struktur Modal terhadap Nilai Peru-} sahaan

Hasil penelitian menunjukkan struktur modal berpengaruh terhadap nilai perusahaan, dengan arah positif. Hal ini menunjukkan semakin tinggi proporsi hutang perusahaan dalam pembiayaan pendanaan perusahaan akan berpengaruh meningkatkan nilai perusahaan. Artinya investor akan merespon kenaikan proporsi hutang perusahaan sebagai sinyal yang positif. Kenaikan struktur modal yang ditunjukkan dengan kenaikan DER menunjukkan adanya kenaikan hutang perusahaan untuk mendanai investasi perusahaan. Kenaiak DER direspon positif oleh investor. Perusahaan yang menerbitkan hutang menunjukkan adanya komitmen manajemen perusahaan untuk meningkatkan kinerjanya. Pe- ningkatan hutang dimata investor menunjukkan manajemen mampu melihat peluang usaha untuk pengembangan usahanya dimasa yang datang. Namun demikian tentunya peningkatan hutang yang dilakukan manajemen tetap harus memperhitungkan kemampuan perusahaan. Peningkatan hutang ini diharapkan mampu berfungsi menjadi leverage atau pengungkit perusahaan.

Hasil penelitian ini mendukung temuan penelitian yang dilakukan oleh Hermuningsih (2013) dimana struktur modal berpengaruh terhadap nilai perusahaan. Namun hasil penelitian ini tidak sesuai dengan penelitian Bilayudha dan Kiswanto (2015); Haryanto (2014); Mardiyati, Gatot dan Putri (2012); Artini dan Puspaningsih (2011), dimana struktur modal tidak berpengaruh terhadap nilai perusahaan.

\section{Pengaruh Kebijakan Deviden terhadap Nilai Perusahaan}

Deviden menunjukkan besarnya laba perusahaan yang dibagikan kepada pemegang saham. Fungsi dari kebijakan pembagian devioden adalah sebagai sinyal kepada investor tentang kinerja perusahaan. Hasil penelitian menunjukkan bahwa kebijakan deviden yang diproksikan dengan DPR tidak berpengaruh terhadap nilai perusahaan. Investor tidak merespon kebijakan deviden sebagai sinyal dari kinerja perusahaan, sehingga tidak berdampak pada nilai perusahaan.

Hal ini dimungkinkan terjadi karena deviden perusahaan yang dibagikan relative kecil. Jika dilihat dari Devident Payout ratio (DPR), yang merupakan perbandingan antara deviden yang dibayar perlembar saham dengan laba bersih perlembar saham, rata-rata nilainya hanya 0,27 . Hal ini menunjukkan bahwa deviden yang dibayarkan kepada pemegang saham hanya sekitar $27 \%$ dari laba bersih perlembar saham.

Kebijakan deviden yang tidak berpengaruh terhadap nilai perusahaan juga dapat terjadi karena investor lebih banyak merupakan investor yang berorientasi jangka pendek. Investor jangka pendek lebih lebih cenderung melihat dari sisi teknikal saham daripada sisi fundamental perusahaan. Sehingga kebijakan deviden, yang merupakan besarnya deviden yang dibayarkan kepada pemegang saham dari laba perusahaan bagi investor jangka pendek tidak begitu penting. Investor lebih melihat dari hirtorical harga saham.

Hasil penelitian ini mendukung temuan penelitian Hasnawati (2005), Artini dan Puspaningsih (2011) dimana kebijakan deviden berpengaruh terhadap nilai perusahaan. Namun 
tidak mendukung penelitian Sofyaningsih dan Hardiningsih (2011) kebijakan deviden tidak berpengaruh terhadap nilai perusahaan.

\section{Pengaruh Profitabilitas terhadap Nilai Perusa- haan}

Profitabilitas merupakan indikator kinerja perusahaan, dimana semakin tinggi profitabilitas kinerja perusahaan semakin baik. Hasil penelitian menunjukkan bahwa profitabilitas yang diukur dengan ROA berpengaruh terhadap nilai perusahaan dengan arah positif. Hasil ini mengindikasikan bahwa profitabilitas mampu menjadi sinyal positif bagi investor. Perusahaan dengan ROA yang semakin besar menunjukkan perusahaan tersebut mampu membukukan laba yang semakin besar dari aset yang dimilikinya. Perusahaan dengan ROA yang tinggi menunjukkan perusahaan tersebut sehat.

Perusahaan dengan profitabilitas yang tinggi, mengindikasikan perusahaan tersebut memiliki prospek yang baik. Sehingga Investor akan merasa lebih aman ketika berinvestasi pada saham-saham tersebut. Saham dari perusahaan dengan prospek yang baik akan harga sahamnya meningkat. Profitabilitas merupakan sinyal positif bagi investor, yang dapat meningkatkan harga saham di pasar. Sehingga nilai perusahaan akan meningkat juga. Sebaliknya perusahaan dengan kinerja yang semakin buruk, mengindikasikan prospek perusahaan tersbut kurang baik. Hasil penelitian ini mendukung temuan penelitian yang dilakukan oleh Haryanto, (2014), dan Hermuningsih (2013).

\section{SIMPULAN DAN SARAN}

Berdasarkan hasil analisis dan pembahasan penelitian menunjukkan bahwa GCG dan kebijakan deviden tidak berpengaruh terhadap nilai perusahaan. Kebijakan struktur modal dan profitabilitas yang merupakan kinerja perusahaan berpengaruh positif terhadap nilai perusahaan pada perusahaan yang masuk Indonesia Most Trusted Companies.

Keterbatasan penelitian ini adalah dari variabel penelitian hanya digunakan dari informasi fundamental perusahaan. Sehingga untuk penelitian selanjutnya dapat memasukkan variabelvariabel makroekonomi. Selain itu dengan periode waktu yang terbatas, yaitu hanya pada tahun 2015 saja sehingga kurang mampu memberikan gambaran yang lengkap. Untuk itu penelitian yang akan dapatang diharapkan dapat melakukan dengan mengambil observasi pada perusa- haan yang masuk Indonesia Most Trusted Companies dengan rentang waktu yang lebih panjang.

\section{DAFTAR PUSTAKA}

Al-Malkawi, H. N. (2007). Determinants of Corporate Devidend Policy in Jordan: An Application of the Tobit Model. Journal of Economic and Administrative Sciences. Vol. $23(2)$

Artini, L. G. S. dan Puspaningsih, N. L. A.. (2011). Struktur Kepemilikan dan Struktur Modal Terhadap Nilai Perusahaan. Jurnal Keuangan dan Perbankan. Vol.15 (1).

Bilayudha, F. dan Kiswanto. (2015). Determinan Nilai Perusahaan Pada Pertambangan Yang Terdaftar Di BEI. Accounting Analysis Journal. Vol. 4(3).

Chandrain, G. (2017). Metode Riset Akmuntansi.: Pendekatan Kuantitatif. Jakarta: Salemba Empat.

Dewi, P. Y. S., Yuniarta, G. A., \& Dewi, A. W. T. (2014). Pengaruh Struktur Modal, Pertumbuhan Perusahaan dan Profitabilitas terhadap Nilai Perusahaan pada Perusahaan LQ 45 di BEI Periode 2008-2012. EJournal S1 Akuntansi, 2 (1): 1-10.

Emirzon, J. (2006). Regulatory driven dalam implementasi prinsip-prinsip good corporate governance pada perusahaan di Indonesia. Jurnal Manajemen $\mathcal{E}$ Bisnis Sriwijaya, 4 (8): 92-114.

Hasnawati, S. (2005). Dampak Set Peluang Investasi Terhadap Nilai Perusahaan Publik di Bursa Efek Jakarta. JAAI Vol. 9 (2)

Haryanto, S. (2014). Identifikasi Ekspektasi Investor melalui Kebijakan Struktur Modal, Profitabilitas, Ukuran Perusahaan dan GCPI. Jurnal Dinamika Manajemen. Jurnal Dinamika Manajemen, Vol. 5 (2): 183 199.

Hermuningsih, S. (2013). Pengaruh Profitabilitas, Growth Opportunity, Sruktur Modal Terhadap Nilai Perusahaan Pada Perusahaan Publik di Indonesia. Buletin Ekonomi Moneter Dan Perbankan, 127-148.

Hermuningsih, S. (2012). Pengaruh Profitabilitas, Size Terhadap Nilai Perusahaan dengan Struktur Modal Sebagai Variabel intervening. Jurnal Siasat Bisnis, Vol. 16 (2) 
Hermuningsih, S. dan Wardani, D. K. (2009). Faktor-Faktor yang Mempengaruhi Nilai Perusahaan pada perusahaan yang Terdaftar di Bursa Efek Malaysia dan Bursa Efek Indonesia. Jurnal Siasat Bisnis, Vol. 13: 173-183.

Heyvon, H. Chandrarin, G. Sumiyana and Anwar, F. (2017) The Influence of Board Dirversity on Financial Performance: An Empi-rical Study of Asia-Pacific Companies Using Regression Models. International Business Management, 11:89-99.

Jandik, T \& Makhija, A.K. (2005). Debt, Debt Structure and Corporate Performance after Unsuccessful Takeover: Evidence from Targets that Remain Independent. Journal of Corporate Finance 11.

Jensen, M. C., \& Meckling, W. H. (1976). Theory of the Firm: Managerial Behavior, Agency Costs and Ownership Structure. Journal of Financial Economics, Vol. 3 (4): 305-360. https://doi.org/http://dx.doi.org/10.10 16/0304-405X(76)90026-X

Juniarti, J. (2013). Good Corporate Governance and Predicting Financial Distress Using Logistic and Probit Regression Model. Jurnal Akuntansi Dan Keuangan, Vol. 15 (1): 1-15. https://doi.org/10.9744/jak.15.1.43-50

Mardiyati, U. Ahmad, G. N. dan Putri, R. (2012). Pengaruh Kebijakan Deviden, Kebijakan Hutang dan Profitabilitas Terhadap Nilai Perusahaan Manufaktur Yang Terdaftar Di BEI Periode 2005-2010. Jurnal Riset Manajemen Sains Indonesia (JRMSI). Vol. 3(1)

Margaritis, D., \& Psillaki, M. (2010). Capital structure, equity ownership and firm performance. Journal of Banking and Finance, Vol. 34(3)

Nafi'ah, Z. (2013). Analisis Faktor-Faktor Yang Mempengaruhi Kebijakan Dividen dan Dampaknya Terhadap Nilai Perusahaan Pada Perusahaan Manufaktur Yang Tercatat Di Bursa Efek Indonesia Tahun 2008-2010. Jurnal STIE Semarang. Vol. 5(3)

Rahmawati, I \& Akram. (2007). Faktor-faktor yang Mempengaruhi Kebijakan Deviden dan Pengaruhnya Terhadap Nilai Perusahaan pada Perusahaan-perusahaan di BEJ Periode 2000-2004. Journal Riset Akuntansi
Aksioma. Vol. 6.

Saputra, M. (2010). Pengaruh Corporate Governance Terhadap Nilai Perusahaan di Bursa Efek Indonesia, Jakarta. Journal of Indonesian Applied Economics, 4 (1), 81-92.

Siallagan, H. dan Machfoedz, M. (2006). Mekanisme Corporate Governance, Kualitas Laba dan Nilai Perusahaan. Simposium Nasional Akuntansi (SNA) Padang, 23-26 Agustus 2006

Sujoko dan Ugi, S. (2007). Pengaruh Struktur Kepemilikan Saham, Leverage Faktor Intern dan Faktor Ekstern terhadap Nilai Perusahaan. Jurnal Manajemen dan Kewirausahaan. Vol. 9(1).

Susanto, M. dan Juniarti. (2013). Pengaruh Good Corporate Governance (GCG) Pada Variabel Ukuran, Debt Ratio Dan Sektor Industri Terhadap Nilai Perusahaan. Business Accounting Review. Vol. 1 (2)

Wardoyo dan Veronica, T. M. (2013). Pengaruh Good Corporrate Governance, Corporrate Social Responsibility, \& Kinerja Keuangan Terhadap Nilai Perusahaan. Jurnal Dinamika Manajemen, Vol. 3 (2), 59-68.

Swa 27 XXIX 19 Desember 2013-8 Januari 2014.

Swa 27 XXXI 21 Desember 2015-6 Januari 2016. 